\title{
Effects of Student-Induced Trampling on Aquatic Macroinvertebrates in Agricultural Headwater Streams
}

\author{
Jon P. Bossley ${ }^{1,2, *}$ (D) and Peter C. Smiley, Jr. ${ }^{3}$ \\ 1 Environmental Science Graduate Program, The Ohio State University, 3138A Smith Lab, 174 West 18th, \\ Columbus, $\mathrm{OH} 43210$, USA \\ 2 Biology Department, School of Natural and Social Sciences, Mount Vernon Nazarene University, \\ 800 Martinsburg Road, Mount Vernon, OH 43050, USA \\ 3 USDA Agricultural Research Service, Soil Drainage Research Unit, 590 Woody Hayes Drive, Columbus, \\ OH 43210, USA; rocky.smiley@ars.usda.gov \\ * Correspondence: jon.bossley@mvnu.edu; Tel.: +1-740-397-9000 (ext. 3201)
}

Received: 13 September 2017; Accepted: 13 January 2018; Published: 17 January 2018

\begin{abstract}
Outdoor education (OE) stream classes provide students with an opportunity to gain hands-on experience with sampling methods for evaluating stream water quality. Trampling by students as a result of stream classes may disrupt the substrate and negatively impact aquatic macroinvertebrates. The impact of student-induced trampling in headwaters as a result of stream classes on aquatic macroinvertebrates has not been evaluated. Our aim was to document the short-term macroinvertebrate responses to an experimental disturbance that simulated the impacts of trampling by students in riffles within small headwater streams. We measured hydrologic variables, visually estimated substrate composition and sampled aquatic macroinvertebrates within control and experimental riffles in three agricultural headwater streams in central Ohio one day prior to experimental disturbance, immediately after disturbance and one day after disturbance. Hydrologic variables and substrate type did not differ daily or between riffle types. Macroinvertebrate abundance, percentage of Ephemeroptera Plecoptera Trichoptera and percentage of Leuctridae increased after experimental disturbance, while diversity, evenness, percentage of clingers and non-metric multidimensional scaling (NMS) axis 1 site scores declined after disturbance. Macroinvertebrate diversity, percent clingers and NMS axis 1 site scores were lower in experimental riffles than control riffles. None of the macroinvertebrate response variables exhibited a significant interaction effect of day $\times$ riffle type that is indicative of an effect of the experimental disturbance. Our results suggest the one-time use of an undisturbed riffle within an agricultural headwater stream for an OE stream class is not likely to impact aquatic macroinvertebrates.
\end{abstract}

Keywords: before-after-control-impact design; field experiment; community structure; hydrologic responses; riffles; disturbance; outdoor education

\section{Introduction}

Natural disturbances, such as floods and droughts, play a prominent role in structuring stream communities and have been the focus of much research [1,2]. A lesser researched disturbance type is instream trampling due to the movements and feeding activity of animals and recreational activity of humans. As with floods, trampling disturbance functions as a pulse disturbance in that the event moves through a stream system quickly but it can cause long-term impact. For instance, trampling and associated grazing by wild herbivores such as hippopotamuses (Hippopotamus amphibious), elk (Cervus canadensis) and moose (Alces alces) and agricultural herbivores such as cattle (Bos taurus) 
have been shown to negatively impact riparian trees, shrubs and forbs [3-7]. Trampling by animals has also resulted in deleterious effects on soil and stream channel structure including soil compaction $[3,4]$, erosion [7,8], streambank sloughing [5], channel widening [9] and increased sedimentation [9,10].

Streams are also frequently subjected to anthropogenic disturbances that alter physical habitat, water chemistry and stream macroinvertebrates such as stream channelization, land use changes and chemical pollution [11,12]. Trampling due to human recreational use of natural areas is a distinct form of anthropogenic disturbance and one that has become the focus of research in recent years. For instance, experimental simulations of trampling on stream macroinvertebrates in Australia and Brazil indicated that changes in macroinvertebrate taxa composition and declines in taxa richness and abundance occurred immediately after trampling $[13,14]$. These experimental simulations also indicated that it would take more than five days for macroinvertebrate community structure to recover from trampling $[13,14]$. Field studies evaluating the impacts of instream hiking (i.e., trampling throughout the stream, typically upstream and downstream) and stream crossings (i.e., cross-channel trampling) by hikers, horseback riders and other recreationists in the United States have documented mixed macroinvertebrate responses. Instream hiking and other outdoor recreational activities led to reductions of macroinvertebrate abundance, diversity and Trichoptera population densities within streams in Oregon and Nebraska $[15,16]$. Localized trampling at stream crossings by hikers, horseback riders and other recreationists reduced macroinvertebrate-based biotic indices, decreased the abundance of sensitive taxa and increased the proportion of tolerant taxa below stream crossings compared to upstream locations in California and Virginia streams [17,18]. However, others [19,20] observed that instream hiking and localized instream wading did not negatively impact stream macroinvertebrate communities in Utah and Missouri.

Streams are commonly located within or flow through parks and other natural areas designated for human use. These managed natural areas are often designated for outdoor recreation use but many of these areas also serve as the locations for outdoor education $(\mathrm{OE})$ programs that teach participants about terrestrial and aquatic ecosystems. OE programs offering classes focused on aquatic ecosystems have become popular at nature centers, camps, parks and schools in the United States [21-24]. Participants in stream classes learn about the ecology of aquatic organisms and how they serve as water quality indicators. The potential impacts of stream classes on aquatic macroinvertebrates likely depends on the frequency and size of the classes, whether the same stream site or multiple sites are used and the sampling methods employed by the students. Educational programs associated with schools adopting a local stream are likely to have small class sizes and to make infrequent visits ( $<4$ times a year) to one or more stream sites and are subsequently not likely to negatively impact aquatic macroinvertebrates. In contrast, day-use nature centers, parks and camps that host multi-day OE programs often serve large numbers of students each year and may conduct stream classes regularly throughout the year within the same site. Such high use programs conducted at the same site have been shown to negatively impact macroinvertebrate abundance, taxa richness, EPT (Ephemeroptera, Plecoptera, Trichoptera) abundance and clinger abundance and cause greater movement of streambed substrate in a fourth order stream in central Ohio $[25,26]$. During conditions of elevated discharge OE stream classes may be cancelled or relocated to small headwater streams to avoid unsafe conditions [26]. However, no previous studies have examined the impact of student-induced trampling resulting from stream classes on aquatic macroinvertebrate communities in small headwater streams.

Our aim was to document the short-term responses of macroinvertebrates to an experimental simulation of trampling by students that results from conducting OE stream classes within small headwater streams. This study was one of four studies conducted at multiple spatial and temporal scales from 2013 to 2015 to quantify the influence of OE stream classes on aquatic macroinvertebrates [25-27]. We hypothesized that within headwater streams in central Ohio a pulse disturbance simulating the impacts of student-induced trampling will cause an immediate negative impact on the macroinvertebrate community in experimentally disturbed riffles followed by a rapid recovery trend, while no disturbance-related changes in community structure will occur in control 
riffles. We concluded that one-time use of small, agricultural headwater streams does not negatively impact the macroinvertebrate community and that the impacts of prolonged or repeated use by $\mathrm{OE}$ stream classes needs to be evaluated further.

\section{Methods}

Three tributaries located along a $2 \mathrm{~km}$ stretch of Alum Creek in central Ohio (latitudes $40^{\circ} 22^{\prime} 31^{\prime \prime}-40^{\circ} 23^{\prime} 56^{\prime \prime} \mathrm{N}$, longitudes $82^{\circ} 50^{\prime} 40^{\prime \prime}$-longitudes $82^{\circ} 52^{\prime} 56^{\prime \prime} \mathrm{E}$ ) were selected as study streams. All tributaries were first or second order streams that were located on or near the property owned by Heartland Outdoor School (Heartland), which granted permission to access these streams. The tributaries were selected because none were used as part of Heartland's stream education classes and subsequently had not been subjected to substrate disruption caused by students and instructors (i.e., trampling and macroinvertebrate collection with use of dipnets and turning over rocks). Examination of historical aerial photography from 1995 to 2015 available in Google Earth also confirmed that none of the tributaries experienced large scale riparian or channel disturbance in the past two decades. Watershed size and stream length varied among tributaries but all were similar in gradient and having watersheds consisting mostly of agricultural land use, especially within the upper reaches (Table 1). Predicted annual mean discharge and June mean discharge were lowest in the smallest tributary and greatest in the largest tributary (Table 1). Additionally, we have observed that streams of similar watershed size in this region of Ohio dry up during periods of low flow in the summer and fall.

Table 1. Watershed and predicted hydrologic characteristics of three agricultural headwater streams of Alum Creek, $\mathrm{OH}, \mathrm{USA}$. All watershed and predicted hydrologic variables except percent agriculture were obtained for each tributary from StreamStats 4.0 [28]. Percent agriculture calculated as the difference between 100 and the sum of percent forest, wetlands/open water and urban areas reported by StreamStats 4.0 [28]. This calculation method for percent agriculture resulted in values from IR that were similar to those obtained from the Great Lakes Long-Term Hydrologic Impact Assessment Model [29].

\begin{tabular}{cccc}
\hline Variable & WR & HR & IR \\
\hline Watershed size $\left(\mathrm{km}^{2}\right)$ & 1.0 & 2.4 & 3.2 \\
Stream length $(\mathrm{km})$ & 2.5 & 3.2 & 4.1 \\
Stream order HR value $(\mathrm{LR}$ value) & 1 & 2 & 2 \\
Gradient $(\mathrm{m} / \mathrm{km})$ & 7.3 & 8.2 & 8.1 \\
Percent forest & 45 & 20 & 27 \\
Percent wetlands and open water & 0 & 0 & 0.2 \\
Percent urban & 3 & 1 & 3 \\
Percent agriculture & 51 & 79 & 70 \\
Annual mean discharge $\left(\mathrm{m}^{3} / \mathrm{s}\right)$ & 0.010 & 0.027 & 0.035 \\
25th percentile discharge $\left(\mathrm{m}^{3} / \mathrm{s}\right)$ & 0.001 & 0.004 & 0.005 \\
50th percentile discharge $\left(\mathrm{m}^{3} / \mathrm{s}\right)$ & 0.004 & 0.011 & 0.014 \\
75th percentile discharge $\left(\mathrm{m}^{3} / \mathrm{s}\right)$ & 0.010 & 0.027 & 0.035 \\
June mean discharge $\left(\mathrm{m}^{3} / \mathrm{s}\right)$ & 0.007 & 0.018 & 0.024 \\
\hline
\end{tabular}

We selected riffles located in the downstream reach of each tributary within $400 \mathrm{~m}$ of the tributaries' confluence with Alum Creek as sampling sites. Riparian zones immediately adjacent to these downstream reaches were wide (mean widths ranging from 171 to $340 \mathrm{~m}$ ) and composed primarily of mature hardwood trees, which resulted in heavy canopy cover $(>85 \%)$ over the selected riffles. Stream substrate consisted mostly of gravel and cobble within the three tributaries but minor differences in rock type occurred among the streams. Two tributaries (WR, IR) contained gravel and cobble consisting of mostly rounded sandstone and granite, while the third tributary (HR) contained gravel and cobble consisting of flat or block-shaped shale particles. 
To address our hypothesis we measured hydrologic variables, estimated substrate composition and sampled aquatic macroinvertebrates within control and experimental riffles within three agricultural headwater streams one day prior to experimental disturbance, immediately after experimental disturbance and one day after experimental disturbance. Our study was conducted from 5 to 14 June 2015. Our experimental design was a combination of a randomized block and a before-after-control-impact design. Each tributary was a block containing one control riffle and one experimental riffle. The control and experimental riffles were each $3 \mathrm{~m}$ long and were separated by a minimum of $45 \mathrm{~m}$ and with at least one stream bend and another riffle between them. The experimental riffle was located downstream of the control riffle in each tributary to avoid potential confounding influences of disturbance-induced macroinvertebrate drift from the experimental riffle. The control riffles were not subjected to experimental disturbance during the study. Experimental riffles were subjected to substrate disruption by kick-shuffling the substrate in a way that would mimic disturbance caused by repeated use of the site by stream classes. Heartland repeatedly conducts stream classes within a riffle in the adjacent Alum Creek at an average of 4 stream classes per day in May and June. Each stream class contains at least 20 students, who along with their instructors, wade through the riffle, turn over rocks and disrupt the substrate in the process of searching for aquatic macroinvertebrates. Thus, we assume that complete substrate disruption would occur if Heartland were to conduct stream classes within these small tributaries.

We disturbed the substrate within each experimental riffle by walking in shoulder-width horizontal rows ( $\sim .5 \mathrm{~m}$ wide) across the riffle while plowing into the sediment to ankle depth ( $\sim 10 \mathrm{~cm}$ deep). The kick-shuffling process began at the downstream boundary of each experimental riffle, progressed to the upstream boundary and then continued back to the downstream boundary. Overlap occurred between rows such that each row was disturbed at least four times during the process resulting in disturbance of $100 \%$ of the riffle bed. The entire process took approximately five minutes and modeled experimental substrate disturbances used by other field experiments [30-33] evaluating the impacts of disturbance on stream macroinvertebrates.

The order in which each tributary was sampled and subjected to substrate disturbance was randomly selected. The order of sampling and disturbance were: (1) 5-7 June 2015-WR; (2) 9-11 June 2015-HR; and (3) 12-14 June 2015-IR. We sampled the control and experimental riffles in each tributary (block) over a three day period. The first day of sampling represented the pre-disturbance sampling period and on this day the control and experimental riffle did not receive any substrate disturbance. On the second day, the experimental riffle was first disturbed by the kick-shuffling process described above and sampling occurred in the experimental riffle immediately following the disturbance. On the second day, the control riffle was not disturbed and sampling was conducted after sampling in the experimental riffle was completed. The third day represented $24 \mathrm{~h}$ post-disturbance and the experimental riffle was sampled first and then the control riffle. Additionally, no substrate disturbance occurred in either riffle on the third day.

Within each riffle we established three permanent cross-channel transects $1 \mathrm{~m}$ apart for hydrologic measurements. From each riffle on each day we obtained one measurement of wetted width, three measurements of water depth located equidistantly apart along each transect and three measurements of surface water velocity from each transect. Wetted width was measured with a tape measure and water depths were measured with a ruler. Water velocity was measured at each transect by releasing a ping pong ball in the center of the fixed plots and timing how long it took to travel $1 \mathrm{~m}$. Three velocity measurements were obtained from each transect and then averaged to represent the surface water velocity at each transect. One (JPB) of us visually estimated substrate composition within each riffle on each sampling day to assess the dominant substrate type (i.e., clay, silt, sand, gravel, cobble, boulders).

Aquatic macroinvertebrates were collected with a Surber sampler $(500 \mu \mathrm{m}$ mesh size, $30.48 \mathrm{~cm} \times 30.48 \mathrm{~cm}$ frame) with the substrate disturbed by hand to a depth of $10 \mathrm{~cm}$ or to an impenetrable hard layer, whichever was encountered first. In each cross-channel transect used for 
hydrologic measurements we established a fixed location for Surber sampling. The fixed plots were located in the center of active flow of each transect, which was usually near the center of the wet width. One Surber sample was taken from each fixed location on each day beginning at the downstream transect and working upstream. Aquatic macroinvertebrates from each Surber sample were transferred to a picking pan and identified in the field with a dissecting microscope having up to $20 \times$ magnification. All macroinvertebrates captured except Hydracarina, Oligochaeta and Planaria were identified to family level. The level of taxonomic resolution used was due to the necessity of identifying animals in the field as part of our catch and release protocol. Our research in an adjacent fourth order stream [27] and others indicate that family level identifications are adequate for evaluating the impacts of student-induced trampling $[7,14]$. After identification and enumeration all macroinvertebrates were returned to the plot from which they were captured. This capture and release protocol provided the live individuals with an opportunity to recolonize the plot from which they were captured and reduced potential human impact on the macroinvertebrate community [13]. This protocol also enabled us to reduce sampling bias that could result from repeatedly sampling fixed plots with permanent removal of individuals [34].

For each riffle on each sampling day we calculated eight community response variables consisting of: (1) macroinvertebrate abundance (number of macroinvertebrates captured); (2) taxa richness (number of taxa); (3) Shannon diversity [35]; (4) evenness (calculated as 1/D) [36]; (5) clinger abundance (number of macroinvertebrates in the clinger mobility guild defined as families Elmidae, Heptageniidae, Baetidae, Helicopsychidae, Glossosomatidae, Hydropsychidae, Philopotamidae, Polycentropodidae, Psephenidae, Simuliidae) [37,38]; (6) percent clingers (percent composition of clinger macroinvertebrates calculated as clinger abundance divided by macroinvertebrate abundance); (7) percent EPT (percentage of macroinvertebrates in orders Ephemeroptera, Plecoptera, Trichoptera calculated as EPT abundance divided by macroinvertebrate abundance); (8) percent Leuctridae (calculated as Leuctridae abundance divided by macroinvertebrate abundance). We also conducted non-metric multidimensional scaling (NMS) with the percentages of the eight most commonly captured taxa to obtain the site scores from the first two NMS axes that describe the changes in taxa composition that occurs among each riffle on each sampling day (one day before, immediately after disturbance and one day after). NMS was conducted with PC-ORD (version 6.17) [39] using the Sorensen (Bray Curtis) distance matrix and 500 iterations. Differences in NMS site scores among days and riffle types were then quantified with linear mixed effect model analyses. This two-step analytical approach is an indirect gradient analysis where ordination is conducted only with community data and the relationships of taxa composition with habitat variables or different habitat categories are then determined with additional statistical tests [40-42]. Additionally, we calculated three hydrologic variables (mean wetted width, mean water depth, mean water velocity) from each riffle on each sampling day. Composited values of community response variables and mean values of hydrologic variables were calculated for each riffle on each day to reduce the amount of pseudoreplication that would occur if we used each individual Surber sample as the replicate in the statistical analyses. As a result, the total sample size in all statistical analyses is 18 .

We conducted a linear mixed effect model analysis with site and day as the fixed factors and tributary as the random factor (i.e., block) using the lmer function within the lme4 package [43]. The primary focus of the linear mixed effect model analysis was the detection of significant interaction effects of site and day because the detection of effects of before-after-control-impact designs is dependent on observing that the trend in response variables between riffle types changes after the disturbance [44]. A significant single factor effect of site (riffle type) simply indicates that the response variable differed between riffle types in the same way across all sampling days. Additionally, a single factor effect of day indicates that the response variable differed among days the same way in both control and experimental riffles. For linear mixed effect model analyses we used the ANOVA function in the car package [45] to obtain the Type III analysis of variance tables. Prior to linear mixed effect model analyses we examined normal q-q plots created with the qqPlot function in the car package [45], 
conducted the Shapiro-Wilk normality test using the shapiro.test function [46] and conducted the Levene's test for homogeneity of variance with the leveneTest function in the car package [45] to determine if the response variables met the assumptions of normality and equal variance. Those seven response variables that did not meet the assumptions were either $\log (x+1)$ transformed (wetted width, mean depth, mean velocity, clinger abundance, evenness, NMS axis 1 site scores) or arcsine square root transformed (percent clingers) prior to linear mixed effect model analyses. Tukey Test (lsmeans function, lsmeans package) [47] was used to determine differences among means if the linear mixed effect model analyses indicated that a significant effect occurred. Linear mixed effect model analyses, Tukey Tests, normal q-q plots, Shapiro-Wilk normality tests and Levene's tests for homogeneity of variances were conducted with R [46] and a significance level of 0.05 .

\section{Results}

Mean wetted width, water depth and water velocity did not differ among days, between riffle types, or exhibit a significant day $\times$ riffle type interaction effect (Table 2). Visual estimates of substrate composition indicated that substrate composition did not differ daily, between riffle types, or in response to substrate disturbance. Riffles within WR and IR were composed primarily of gravel with some cobble and boulders. Riffles within HR were composed primarily of a mixture of gravel and cobble. Although substrate composition did not change, our experimental disturbance within the experimental riffles resulted in movement of individual substrate particles because rows from where the kick-shuffling took place were still visible on the last day of sampling within the experimental riffles of two tributaries (WR, HR). We also observed that the experimental disturbance resulted in a temporary increase (i.e., 2 to $8 \mathrm{~min}$ ) in turbidity in the experimental riffles.

Table 2. $p$-values from linear mixed effect model analysis of the effect of sampling day, site and the interaction effect of day and site on hydrologic and aquatic macroinvertebrate community response variables within three agricultural headwater streams of the upper Alum Creek, OH, USA from 5 to 14 June 2015. Bolded $p$-values are those that were significant $(p<0.05)$. Abbreviations are EPT-Ephemeroptera, Plecoptera, Trichoptera; NMS—non-metric multidimensional scaling.

\begin{tabular}{cccc}
\hline Response Variable & Day & Site & Day $\times$ Site \\
\hline Wetted width & 0.162 & 0.416 & 0.989 \\
Water depth & 0.164 & 0.416 & 0.989 \\
Water velocity & 0.118 & 0.791 & 0.779 \\
Abundance & $\mathbf{0 . 0 0 4}$ & 0.465 & 0.477 \\
Taxa richness & 0.277 & 0.799 & 0.549 \\
Shannon diversity index & $\mathbf{0 . 0 0 3}$ & $\mathbf{0 . 0 1 6}$ & 0.759 \\
Evenness & $\mathbf{0 . 0 1 1}$ & 0.125 & 0.257 \\
Clinger abundance & $\mathbf{0 . 0 4 5}$ & 0.074 & 0.423 \\
Percent clingers & $\mathbf{0 . 0 0 4}$ & $\mathbf{0 . 0 1 4}$ & 0.518 \\
Percent EPT & $\mathbf{0 . 0 0 3}$ & 0.081 & 0.634 \\
Percent Leuctridae & $\mathbf{0 . 0 0 1}$ & $\mathbf{0 . 0 4 2}$ & 0.570 \\
NMS axis 1 site scores & $\mathbf{0 . 0 0 1}$ & $\mathbf{0 . 0 2 4}$ & 0.555 \\
NMS axis 2 site scores & $\mathbf{0 . 0 3 3}$ & 0.156 & 0.833 \\
\hline
\end{tabular}

We documented 25 taxa from 2873 captures during our study. The eight most abundant taxa (i.e., Leuctridae, Hydracarina, Chironomidae, Hydropsychidae, Tipulidae, Baetidae, Philopotamidae and Elmidae) comprised $97 \%$ of all captures and were captured in each riffle type on each sampling day (Table 3). Notably, Leuctridae, Hydracarina and Chironomidae were the three most abundant taxa captured within each riffle type on each sampling day (Table 3). Additionally, these three taxa constituted between $79 \%$ and $91 \%$ of all captures within each riffle type on each sampling day (Table 3). The stress of the final two-dimensional solution of NMS ordination of the eight most common taxa was 0.001 , which indicates it is an excellent representation of the taxa composition trends [48]. The first NMS axis represents a gradient of Chironomidae, Hydropsychidae, Hydracarina, Leuctridae and 
Philopotamidae (Figure 1B). Increasing site scores along the first NMS axis indicate increasing relative abundances of Hydropsychidae and Chironomidae and decreasing relative abundances of Hydracarina, Leuctridae and Philopotamidae (Figure 1B). Conversely, decreasing site scores along the first NMS axis indicate increasing relative abundances of Hydracarina, Leuctridae and Philopotamidae and decreasing relative abundances of Hydropsychidae and Chironomidae (Figure 1B). The second NMS axis represents a gradient of Hydracarina, Baetidae, Hydropsychidae, Chironomidae, Tipulidae and Leuctridae (Figure 1B). Increasing site scores along the second NMS axis represent increasing relative abundances of Hydracarina and Baetidae and decreasing relative abundances of Hydropsychidae, Chironomidae, Tipulidae and Leuctridae (Figure 1B). Decreasing site scores along the second NMS axis represent increasing relative abundances of Hydropsychidae, Chironomidae, Tipulidae and Leuctridae and decreasing relative abundances of Hydracarina and Baetidae (Figure 1B).
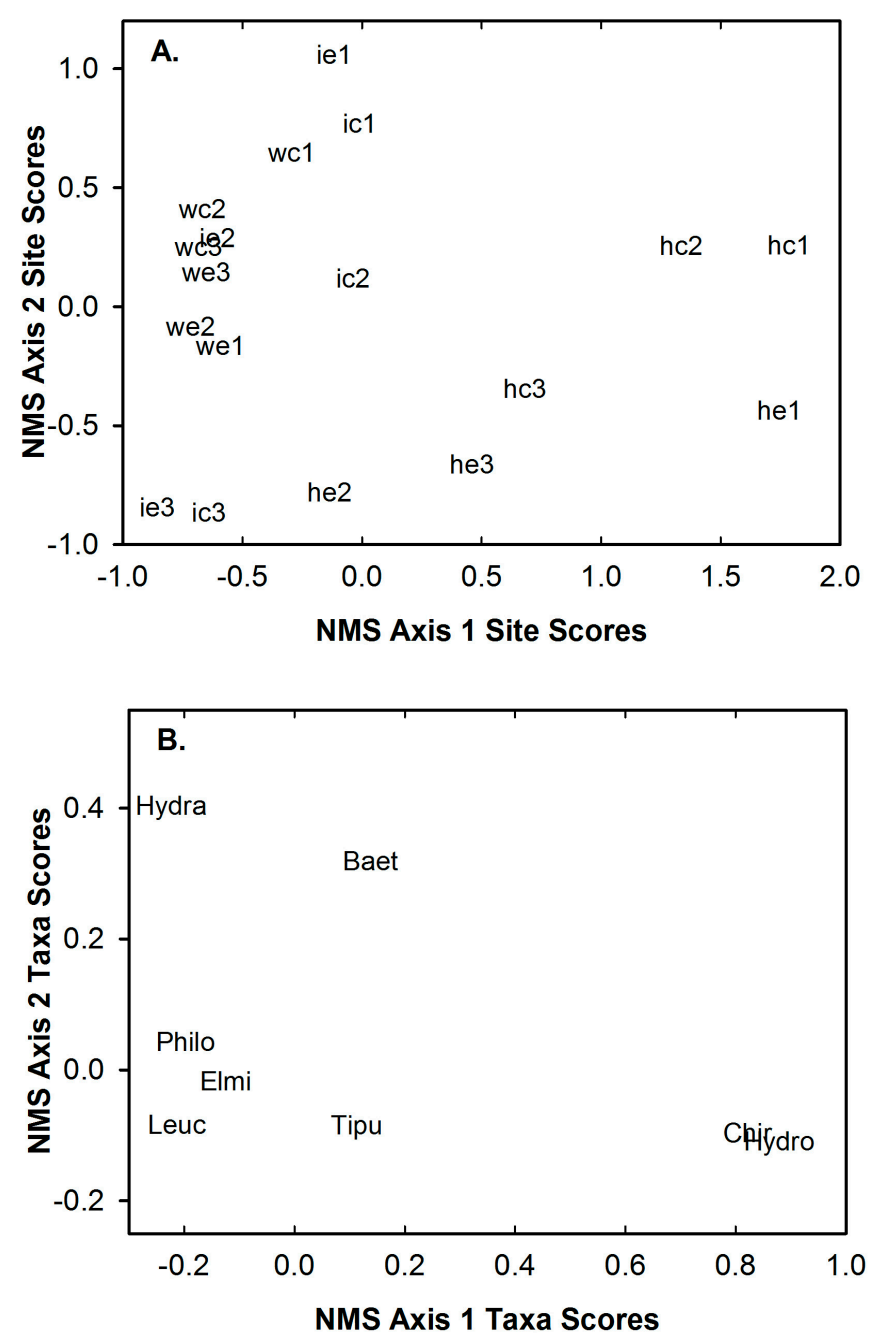

Figure 1. Site scores (A) and taxa scores (B) from the non-metric multidimensional scaling of the eight most common macroinvertebrate taxa captured one day before, immediately after and one day after experimental substrate disturbance in control and experimental riffles within three agricultural headwater streams of upper Alum Creek, 5-14 June 2015. The two letter and number abbreviations for sites (collections) consist of codes for tributary (h-HR; i-IR; w-WR), riffle type ( $c$ - control riffle; $d$-experimental riffle) and day (1-one day before disturbance; 2-immediately after disturbance; 3-one day after disturbance. Abbreviations for taxa are: Hydra-Hydracarina; Baet-Baetidae; Philo-Philopotamidae; Elmi-Elmidae; Leuc-Leuctridae; Tipu-Tipulidae; Chiro-Chironomidae; Hydro-Hydropsychidae. 
Table 3. Total number of captures (\%) and number of captures of macroinvertebrate taxa on each day (one day before, immediately after, one day after experimental disturbance) within each site type (control, experimental) within three agricultural headwater streams of upper Alum Creek, 5-14 June 2015.

\begin{tabular}{|c|c|c|c|c|c|c|c|}
\hline \multirow{2}{*}{ Taxa } & \multirow{2}{*}{ Total } & \multicolumn{2}{|c|}{ Day Before } & \multicolumn{2}{|c|}{ Immediately After } & \multicolumn{2}{|c|}{ Day After } \\
\hline & & Control & Experimental & Control & Experimental & Control & Experimental \\
\hline Leuctridae & $1858(64.7)$ & 116 & 161 & 279 & 467 & 413 & 422 \\
\hline Hydracarina & $463(16.1)$ & 70 & 68 & 111 & 114 & 58 & 42 \\
\hline Chironomidae & $164(5.7)$ & 25 & 29 & 32 & 22 & 35 & 21 \\
\hline Hydropsychidae & $102(3.6)$ & 21 & 15 & 20 & 26 & 14 & 6 \\
\hline Tipulidae & $74(2.6)$ & 5 & 9 & 6 & 9 & 27 & 18 \\
\hline Baetidae & $50(1.7)$ & 11 & 10 & 11 & 4 & 11 & 3 \\
\hline Philopotamidae & $33(1.2)$ & 5 & 5 & 3 & 10 & 4 & 6 \\
\hline Elmidae & $32(1.1)$ & 1 & 3 & 12 & 9 & 4 & 3 \\
\hline Leptophlebiidae & $22(0.8)$ & 0 & 3 & 4 & 7 & 6 & 2 \\
\hline Simuliidae & $22(0.8)$ & 6 & 5 & 3 & 2 & 5 & 1 \\
\hline Oligochaeta & $15(0.5)$ & 4 & 0 & 2 & 3 & 3 & 3 \\
\hline Planaria & $8(0.3)$ & 1 & 0 & 1 & 4 & 1 & 1 \\
\hline Corydalidae & $6(0.2)$ & 1 & 0 & 3 & 1 & 0 & 1 \\
\hline Cambaridae & $4(0.1)$ & 0 & 0 & 3 & 0 & 0 & 1 \\
\hline Ceratopogonidae & $3(0.1)$ & 0 & 2 & 0 & 1 & 0 & 0 \\
\hline Pleuroceridae & $3(0.1)$ & 0 & 0 & 0 & 1 & 2 & 0 \\
\hline Veliidae & $3(0.1)$ & 0 & 0 & 3 & 0 & 0 & 0 \\
\hline Heptageniidae & $2(<0.1)$ & 0 & 0 & 0 & 1 & 0 & 1 \\
\hline Polycentropodidae & $2(<0.1)$ & 0 & 0 & 0 & 0 & 1 & 1 \\
\hline Gomphidae & $1(<0.1)$ & 0 & 0 & 0 & 1 & 0 & 0 \\
\hline Nemouridae & $1(<0.1)$ & 0 & 0 & 0 & 0 & 1 & 0 \\
\hline Perlidae & $1(<0.1)$ & 1 & 0 & 0 & 0 & 0 & 0 \\
\hline Physidae & $1(<0.1)$ & 0 & 0 & 0 & 1 & 0 & 0 \\
\hline Psephenidae & $1(<0.1)$ & 0 & 0 & 1 & 0 & 0 & 0 \\
\hline Tabanidae & $1(<0.1)$ & 0 & 0 & 0 & 0 & 0 & 1 \\
\hline Unknown & $1(<0.1)$ & 0 & 0 & 0 & 0 & 1 & 0 \\
\hline
\end{tabular}

Abundance, Shannon diversity index, evenness, clinger abundance, percent clingers, percent EPT, percent Leuctridae and the site scores of NMS axes 1 and 2 differed daily (Table 2). Shannon diversity index, percent clingers, percent Leuctridae and the site scores of NMS axis 1 differed between riffle types (Table 2). None of the ten macroinvertebrate community response variables exhibited a significant day $\times$ site interaction effect (Table 2, Table A3 in the Appendix A). Mean abundance was lowest one day before substrate disturbance and greatest immediately after (Figure 2A). Mean percent EPT and percent Leuctridae were lowest one day before substrate disturbance and greatest one day after (Figure 2E,F). Mean Shannon diversity index, mean evenness and mean percent clingers were greatest prior to disturbance and lowest one day after (Figure 2B-D). The site scores of NMS axis 1 were also greatest prior to disturbance and lowest one day after (Figure 2G). These daily differences in the site scores of NMS axis 1 indicated that before disturbance the riffles had greater relative abundances of Hydropyschidae and Chironomidae (Figure 1A,B) and one day after disturbance the sampled riffles exhibited greater relative abundances of Hydracarina, Leuctridae and Philopotamidae (Figure 1A,B). Although the linear mixed effect model analysis indicated clinger abundance and the site scores of NMS axis 2 differed daily, no differences among means were found with the Tukey post hoc test. Shannon diversity index, percent clingers, percent Leuctridae and site scores of NMS axis 1 differed between riffle types (Table 2). Mean Shannon diversity index, percent clingers and the site scores of NMS axis 1 were greater in the control riffles than the experimental riffles (Figure 3). Differences in site scores of NMS axis 1 between riffle types indicated that control riffles contained greater relative abundances of Hydropyschidae and Chironomidae (Figure 1A,B) and experimental riffles contained greater relative abundances of Hydracarina, Leuctridae and Philopotamidae (Figure 1A,B). Although the linear mixed effect model analysis indicated percent Leuctridae differed between riffle types, no differences between means were found with the Tukey post hoc test. 

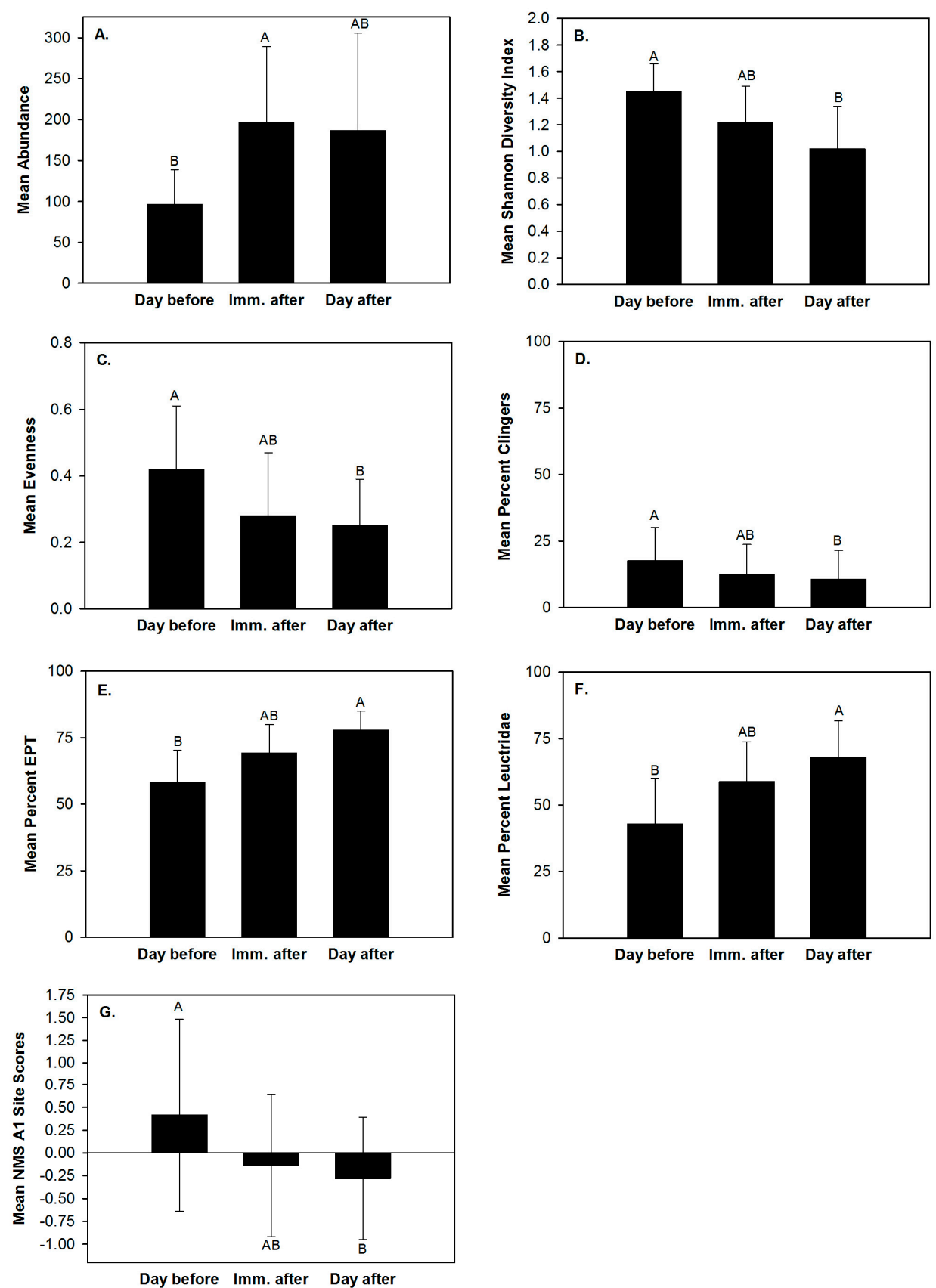

Figure 2. Mean macroinvertebrate abundance (A); Shannon diversity index (B); evenness (C); percent clingers (D); percent EPT (Ephemeroptera, Plecoptera, Trichoptera) (E); percent Family Leuctridae (F); and NMS A1 (non-metric multidimensional scaling axis 1) site scores (G) one day before (day before), immediately after (imm. after) and one day after (day after) experimental substrate disturbance in riffles within three agricultural headwater streams of upper Alum Creek, 5-14 June 2015. Bars with different letters are those with means that differ significantly $(p<0.05)$ from other sampling days. 

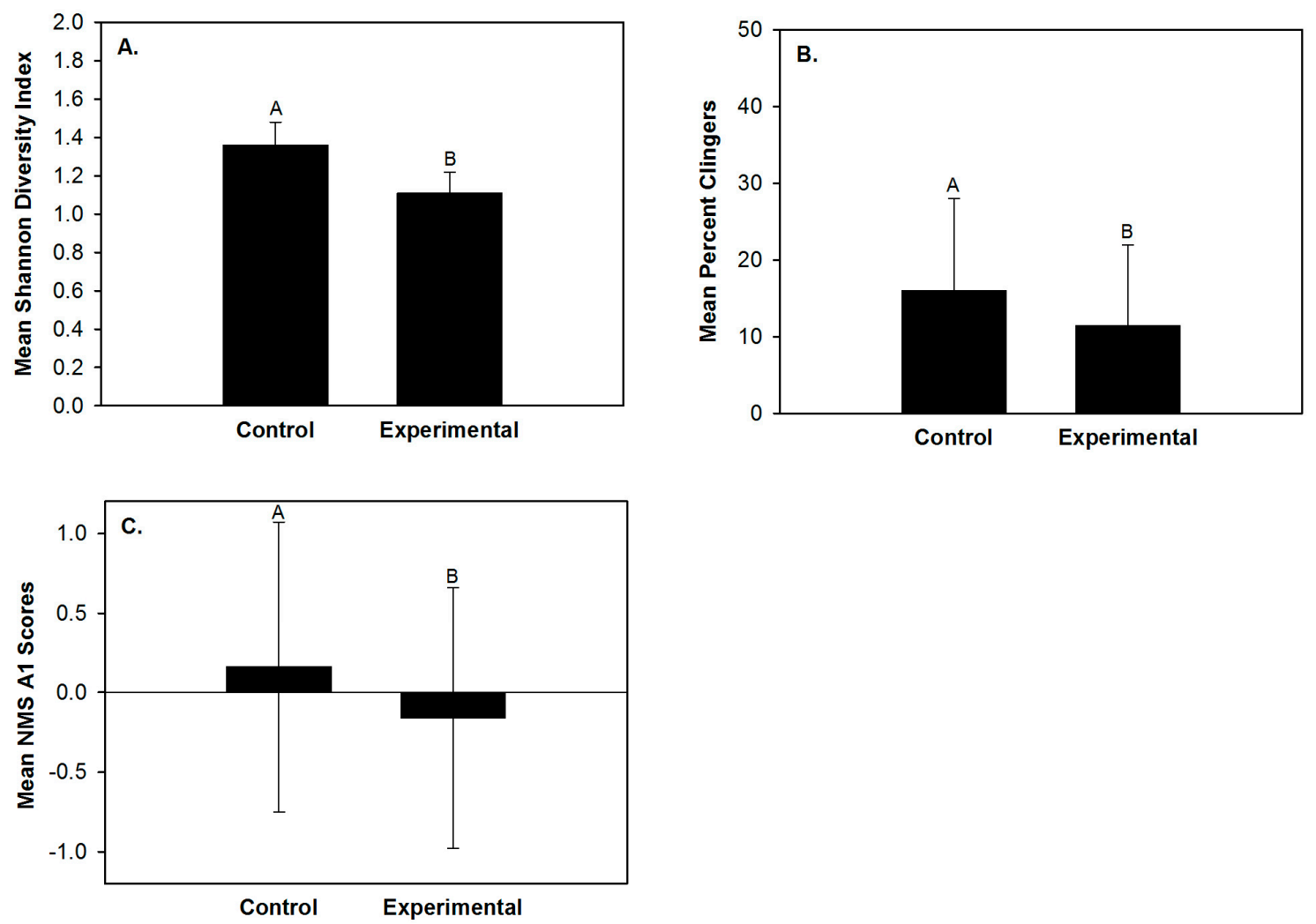

Figure 3. Mean macroinvertebrate Shannon diversity index (A); percent clingers (B); and NMS A1 (non-metric multidimensional scaling axis 1 ) site scores $(\mathbf{C})$ between control and experimental riffles within three agricultural headwater streams of upper Alum Creek, 5-14 June 2015. Bars with different letters are those with means that differ significantly $(p<0.05)$ between riffle types.

\section{Discussion}

Our results did not support our hypothesis that a pulse disturbance simulating the effect of trampling resulting from OE stream classes would cause immediate and short-term impacts on macroinvertebrate community structure within headwater streams in central Ohio. Although we observed differences in macroinvertebrate community structure daily and between riffle types, these were not indicative of the community response variables between control and experimental riffles before and after our simulated pulse disturbance [44].

We anticipated the undisturbed nature of our study sites would increase the likelihood of observing an effect of our experimental disturbance. We also expected that our experimental disturbance would impact aquatic macroinvertebrates because it was conducted similarly to experimental disturbances used by other field experiments [31-33] that documented post-disturbance reductions of taxa richness and abundance. Our study has limited replication ( $n=3$ tributaries) because we only had permission to access these three streams that were located on private property. We acknowledge that we may have needed additional headwater streams (i.e., blocks) to detect an effect of trampling. However, we assume our sampling design was adequate to document obvious changes in physical habitat characteristics and macroinvertebrate community structure. Our physical habitat assessments documented that our simulated disturbance was effective in disrupting the substrate but it did not change the dominant substrate type or hydrologic characteristics. Additionally, hydrologic measurements confirmed that the streams were at baseflow conditions. In contrast, floods that are commonly observed to impact macroinvertebrates result in changes to hydrologic (i.e., increased discharge) and substrate characteristics (i.e., movement and type) [49]. We also observed that the majority of the taxa captured in all riffle types on each sampling day were small-bodied 
macroinvertebrates that may have resided below the sediment surface and been less prone to catastrophic drift or being crushed by moving substrate. Six (Leuctridae, Hydracarina, Chironomidae, Tipulidae, Baetidae, Elmidae) of the eight most common taxa we found have been documented in the hyporheic zone [50-53] and these taxa are all characterized by a flexible, elongate body shape and/or small body size suspected to confer mobility advantages in navigating the interstices [50]. Furthermore, substrate disturbances are known to knock loose and remove fine particles of sediment and organic matter, thus opening more interstitial space for hyporheic dwellers [54]. The increased turbidity in our experimental riffles immediately after experimental disturbance suggests that our substrate disruption throughout the upper $10 \mathrm{~cm}$ of hyporheic zone removed fine particles and may have increased interstitial space that could be colonized from above by dislodged individuals as well as from below by individuals deeper within the hyporheic zone. Thus, we conjecture that our experimental disturbance did not impact the aquatic macroinvertebrate community because: (1) it was a short-term substrate disruption that did not alter the dominant substrate type or hydrologic characteristics; (2) our study sites contained primarily small-bodied hyporheic macroinvertebrates less prone to drift and death from substrate movement; (3) our experimental disturbance opened pore spaces in the surface sediments that were colonized by hyporheic dwellers; or (4) a combination of the previous three factors.

The effects of disturbance on macroinvertebrates and other stream organisms are dependent on the magnitude of the disturbance [49]. Our experimental disturbance was a one-time disturbance conducted at a small spatial scale (i.e., $3 \mathrm{~m}$ of stream), which would not have impacted potential colonizers from upstream and downstream of our experimental riffles or below our $10 \mathrm{~cm}$ disturbance depth. Perhaps increasing the frequency and spatial scale of experimental disturbance would have impacted the aquatic macroinvertebrates within the experimental riffles. However, others have successfully reduced macroinvertebrate abundance and richness with a one-time disturbance of small patches $\left(<2 \mathrm{~m}^{2}\right.$ in size $)$ within riffles [13,31,32]. Therefore, the frequency and spatial scale of our experimental disturbance does not adequately explain our observed results that occurred after disturbance of an entire riffle.

It is also possible that repeated sampling of fixed plots within the riffles may have caused sampling related bias, which resulted in our observation of spatial and temporal differences in macroinvertebrate communities but not an effect of the experimental disturbance. We chose to sample the same plots repeatedly because our previous experience with sampling macroinvertebrates within riffles of streams in central Ohio indicated considerable within riffle variability in macroinvertebrate community structure [25]. Thus, we believed repeatedly sampling the same plots within the riffles would help account for the anticipated within riffle variability and increase the likelihood of observing an effect of our experimental disturbance. Our capture and release protocol also aided in reducing sampling bias. We observed during the field identifications that macroinvertebrates would immediately attach to the nearest substrate when placed in the sorting pan. Given that the flow within the streams was low and similar to the still water in the sorting pans, we assumed that macroinvertebrates released into the stream after identification would also attach to the nearest substrate. Additionally, based on our previous findings [25] we anticipated that if our repeated sampling of the same plots biased our results, then we would have observed consistent daily reductions in all macroinvertebrate community response variables except evenness. This was not the case as some macroinvertebrate response variables increased as the experiment progressed, other response variables decreased and some did not change. We also believed that we controlled for the potential effects of sampling by sampling both control and experimental riffles in the same way. Thus, we conjecture that repeated sampling of the same plots is not likely the underlying cause for our lack of an effect of experimental disturbance.

Our results are consistent with others $[19,20]$ who found that trampling as a result of outdoor recreational use did not impact aquatic macroinvertebrates in streams in Utah and Missouri. Our results contradict the results of experimental simulations and field studies that have documented declines in taxa richness, abundance and the abundances of selected populations and guilds within streams 
in the United States, Brazil and Australia [13-18]. Studies that did not document trampling impacts were conducted in the United States and those documenting trampling impacts were conducted in the United States [15-18] and internationally $[13,14]$. Studies in both categories were conducted in a range of stream sizes from small streams (i.e., first or second order) (our study, $[17,18]$ ) to larger wadeable streams $[13-16,19,20]$. Studies in both categories spanned a range of methods including those consisting of simulated experimental trampling (our study, $[13,14]$ ) and field studies that sampled sites with different levels of trampling or sampled above and below stream crossings [15-20]. Additionally, studies in both categories evaluated the impacts of human trampling (ours, [13-16,19]) and impacts of human and animal trampling $[17,18,20]$. Studies that did not document trampling impacts consisted entirely of short term studies less than six months in duration. Studies documenting trampling impacts consisted mostly of short term studies $[13,14,16,18]$ with only two studies being conducted for a two-year period $[15,17]$. Thus, a clear pattern explaining differences between studies that documented no impact of trampling on macroinvertebrates (our results, $[19,20]$ ) and studies that documented a distinct impact of trampling on macroinvertebrates [13-18] is not readily apparent. However, Wright and Li [15] found that Trichopteran densities were reduced by recreational activities the year before but not the year after a major flood. Discharge records from the USGS gauge located on Alum Creek $6 \mathrm{~km}$ downstream of our tributaries indicate the occurrence of three peaks in discharge that exceeded baseflow values, which in turn suggests the probability of flooding within our tributaries three weeks prior to beginning our experiment that may have influenced our results. Based on the findings of Wright and Li [15], perhaps our results and others [19,20] that did not document the effects of trampling were obscured by prior flooding events, stream drying, or other natural disturbances. Additionally, our results and those of Heth et al. [20] indicated that aquatic macroinvertebrates were more strongly influenced by differences among sampling sites and time periods than by trampling. Future research evaluating the role of natural disturbances in mediating the effect of trampling on aquatic macroinvertebrates and future research further exploring the relative effects of location, time periods and trampling on aquatic macroinvertebrates in streams is needed to gain a better understanding of the impacts of trampling as a result of $\mathrm{OE}$ and recreational activities.

In conclusion, our results suggest that the one-time use of undisturbed riffles within agricultural headwater streams for OE stream classes will not negatively impact the resident aquatic macroinvertebrates. However, many OE organizations often hold numerous stream classes repeatedly in the same sites. The effect of repeatedly using riffles within agricultural headwater streams for stream classes has not been evaluated and needs to be addressed in future research studies. The majority of the research evaluating the effects of repeated trampling on stream macroinvertebrates in larger streams indicates that trampling can negatively impact aquatic macroinvertebrates but post-trampling recovery can occur quickly $[13-18,25,26]$. In light of these findings we recommend that educational organizations that repeatedly use agricultural headwater streams for stream classes adopt precautionary measures such as rotating their usage of class sites to enable the macroinvertebrates to recover from trampling by students.

Acknowledgments: We thank S. Fisher, R. Moore, K. Lekies and D. Denlinger for helpful comments on an earlier draft of this manuscript. We also thank program manager A. Buzbee of Heartland Outdoor School for his support of the project and permission to access sites on the Heartland Outdoor School property for sampling. We are grateful for H. Nguyen's guidance on statistical analyses. Finally, we thank the National Science Foundation for their support of the research conducted by J.P.B through a fellowship provided by the grant Linking Watershed Education with GK-12 Education in a Watershed Context.

Author Contributions: Jon P. Bossley and Peter C. Smiley, Jr. conceived and designed the field experiment; Jon P. Bossley performed the field experiment and conducted macroinvertebrate and instream habitat sampling; Peter C. Smiley, Jr. analyzed the data; Jon P. Bossley and Peter C. Smiley, Jr. wrote the paper.

Conflicts of Interest: The authors declare no conflict of interest. 


\section{Appendix A}

Table A1. Means (SD) of hydrologic and macroinvertebrate community response variables that did not differ among days (one day before, immediately after, one day after experimental disturbance) in riffles within three agricultural headwater streams of upper Alum Creek, 5-14 June 2015.

\begin{tabular}{cccc}
\hline Response Variable & Day Before & Immediately After & Day After \\
\hline Wetted width $(\mathrm{m})$ & $2.4(0.5)$ & $2.4(0.6)$ & $3.6(2.3)$ \\
Water depth $(\mathrm{m})$ & $0.03(0.01)$ & $0.03(0.01)$ & $0.05(0.03)$ \\
Water velocity $(\mathrm{m} / \mathrm{s})$ & $0.26(0.06)$ & $0.27(0.05)$ & $0.38(0.16)$ \\
Taxa richness & $8.5(1.4)$ & $10.2(2.5)$ & $9.7(2.9)$ \\
\hline
\end{tabular}

Table A2. Means (SD) of hydrologic and macroinvertebrate community response variables that did not differ between control and experimental riffles within three agricultural headwater streams of upper Alum Creek, 5-14 June 2015.

\begin{tabular}{ccc}
\hline Response Variable & Control & Experimental \\
\hline Wetted width $(\mathrm{m})$ & $3.0(1.7)$ & $2.6(1.2)$ \\
Water depth $(\mathrm{m})$ & $0.04(0.02)$ & $0.04(0.02)$ \\
Water velocity $(\mathrm{m} / \mathrm{s})$ & $0.28(0.13)$ & $0.33(0.09)$ \\
Abundance & $149.7(93.7)$ & $169.6(104.9)$ \\
Taxa Richness & $9.6(2.0)$ & $9.3(2.7)$ \\
Evenness & $0.4(0.2)$ & $0.3(0.2)$ \\
Clinger abundance & $14.8(5.0)$ & $11.4(6.2)$ \\
Percent EPT & $64.3(10.4)$ & $72.4(13.9)$ \\
NMS axis 2 site scores & $0.17(0.50)$ & $-0.17(0.61)$ \\
\hline
\end{tabular}

Table A3. Means (SD) of hydrologic and macroinvertebrate community response variables that did not exhibit a significant interaction effect of day (one day before, immediately after, one day after experimental disturbance) and riffle types (Control, Experimental) in riffles within three agricultural headwater streams of upper Alum Creek, 5-4 June 2015.

\begin{tabular}{|c|c|c|c|c|c|c|}
\hline Response Variable & \multicolumn{2}{|c|}{ Day Before } & \multicolumn{2}{|c|}{ Immediately After } & \multicolumn{2}{|c|}{ Day After } \\
\hline Wetted width (m) & $2.6(0.6)$ & $2.2(0.2)$ & $2.6(0.8)$ & $2.2(0.2)$ & $3.8(2.9)$ & $3.3(2.1)$ \\
\hline Water velocity $(\mathrm{m} / \mathrm{s})$ & $0.23(0.06)$ & $0.29(0.04)$ & $0.24(0.03)$ & $0.31(0.04)$ & $0.37(0.21)$ & $0.40(0.15)$ \\
\hline Abundance & $89.0(41.6)$ & $103.3(51.5)$ & $164.7(105.8)$ & $227.7(86.3)$ & $195.3(115.1)$ & $177.7(149.0)$ \\
\hline Taxa richness & $8.7(1.5)$ & $8.3(1.5)$ & $9.7(2.3$ & $10.7(3.1)$ & $10.3(2.5)$ & $9.0(3.6)$ \\
\hline Clinger abundance & $14.7(1.5)$ & $10.7(3.5)$ & $16.7(7.6)$ & $16.7(8.3)$ & $13.0(5.3)$ & $7.0(1.0)$ \\
\hline Percent clingers & $20.3(12.3)$ & $15.1(14.5)$ & $16.4(14.7)$ & $8.8(7.4)$ & $11.3(12.0)$ & $10.1(12.2)$ \\
\hline Percent EPT & $55.1(8.4)$ & $61.1(16.4)$ & $62.1(4.9)$ & $76.4(10.1)$ & $75.6(4.5)$ & $79.8(9.9)$ \\
\hline Percent Leuctridae & $38.5(15.9)$ & $47.2(20.6)$ & $49.4(16.5)$ & $68.4(3.8)$ & $65.2(13.8)$ & $70.7(16.1)$ \\
\hline NMS axis 1 site scores & $0.49(1.13)$ & $0.35(1.2)$ & $0.21(1.02)$ & $-0.49(0.31)$ & $-0.21(0.78)$ & $-0.35(0.71)$ \\
\hline NMS axis 2 site scores & $0.56(0.27)$ & $0.15(0.80)$ & $0.26(0.15)$ & $-0.19(0.54)$ & $-0.32(0.56)$ & $-0.45(0.53)$ \\
\hline
\end{tabular}

\section{References}

1. Resh, V.H.; Brown, A.V.; Covich, A.P.; Gurtz, M.E.; Li, H.W.; Minshall, G.W.; Reice, S.R.; Sheldon, A.L.; Wallace, J.B.; Wissmar, R.C. The role of disturbance in stream ecology. J. N. Am. Benthol. Soc. 1988, 7, 433-455. [CrossRef]

2. Stanley, E.H.; Powers, S.M.; Lottig, N.R. The evolving legacy of disturbance in stream ecology: Concepts, contributions and coming challenges. J. N. Am. Benthol. Soc. 2010, 29, 67-83. [CrossRef]

3. Lock, J.M. The effects of hippopotamus grazing on grasslands. J. Ecol. 1972, 60, 445-467. [CrossRef]

4. Kauffman, J.B.; Krueger, W.C. Livestock impacts on riparian ecosystems and streamside management implications. A review. J. Range Manag. 1984, 37, 430-438. [CrossRef] 
5. Armour, C.L.; Duff, D.A.; Elmore, W. The effects of livestock grazing on riparian and stream ecosystems. Fisheries 1991, 16, 7-11. [CrossRef]

6. Kay, C.E. Impact of native ungulates and beaver on riparian communities in the intermountain west. Nat. Resour. Environ. Issues 1994, 1, 23-44.

7. Wohl, N.E.; Carline, R.F. Relations among riparian grazing, sediment loads, macroinvertebrates and fishes in three central Pennsylvania streams. Can. J. Fish. Aquat. Sci. 1996, 53 (Suppl. 1), 260-266. [CrossRef]

8. Deluca, T.H.; Patterson, W.A.; Freimund, W.A.; Cole, D.N. Influence of llamas, horses and hikers on soil erosion from established recreation trails in western Montana, USA. Environ. Manag. 1998, 22, 255-262. [CrossRef]

9. Fritz, K.M.; Dodds, W.K.; Pontius, J. The effects of bison crossings on the macroinvertebrate community in a tallgrass prairie stream. Am. Midl. Nat. 1999, 141, 253-265. [CrossRef]

10. Li, H.W.; Lamberti, G.A.; Pearsons, T.N.; Tait, C.K.; Li, J.L.; John, C.; Buckhouse, J.C. Cumulative effects of riparian disturbances along high desert trout streams of the John Day Basin, Oregon. Trans. Am. Fish. Soc. 1994, 123, 627-640. [CrossRef]

11. Niemi, G.J.; Devore, P.; Detenbeck, N.; Taylor, D.; Lima, A.; Pastor, J. Overview of case studies on recovery of aquatic systems from disturbance. Environ. Manag. 1990, 14, 571-587. [CrossRef]

12. Yount, J.D.; Niemi, G.J. Recovery of lotic communities and ecosystems from disturbance-A narrative review of case studies. Environ. Manag. 1990, 14, 547-569. [CrossRef]

13. Escarpinati, S.C.; Siqueira, T.; Medina, P.B., Jr.; Roque, F.O. Short-term effects of visitor trampling on macroinvertebrates in karst streams in an ecotourism region. Environ. Monit. Assess. 2014, 186, 1655-1663. [CrossRef] [PubMed]

14. Hardiman, N.; Burgin, S. Effects of trampling on in-stream macroinvertebrate communities from canyoning activity in the Greater Blue Mountains World Heritage Area. Wetl. Ecol. Manag. 2011, 19, 61-71. [CrossRef]

15. Wright, K.K.; Li, J.L. Effects of recreational activities on the distribution of Dicosmoecus gilvipes in a mountain stream. J. N. Am. Benthol. Soc. 1998, 17, 535-543. [CrossRef]

16. Laing, K.D. Impacts of Human Physical Disturbance on Benthic Communities in Tributaries of the Niobrara National Scenic River. Master's Thesis, University of Nebraska, Lincoln, NE, USA, May 2008.

17. Holmquist, J.G.; Schmidt-Gengenbach, J.; Roche, J.W. Stream macroinvertebrates and habitat below and above two wilderness fords used by mules, horses and hikers in Yosemite National Park. West. N. Am. Nat. 2015, 75, 311-324. [CrossRef]

18. Kidd, K.R.; Aust, W.M.; Copenheaver, C.A. Recreational stream crossing effects on sediment delivery and macroinvertebrates in southwestern Virgnia, USA. Environ. Manag. 2014, 54, 505-516. [CrossRef] [PubMed]

19. Caires, A.M.; Vinson, M.R.; Brasher, A.M.D. Impacts of hikers on aquatic macroinvertebrates in the North Fork of the Virgin River, Utah. Southwest. Nat. 2010, 55, 551-557. [CrossRef]

20. Heth, R.L.S.; Bowles, D.E.; Havel, J.E. Potential impacts of stream crossing traffic on macroinvertebrate communities in the Missouri Ozark River. River Res. Appl. 2016, 32, 925-934. [CrossRef]

21. Siemer, W.F.; Knuth, B.A. Effects of fishing education programs on antecedents of responsible environmental behavior. J. Environ. Educ. 2001, 32, 23-29. [CrossRef]

22. Fleming, W. Volunteer watershed health monitoring by local stakeholders: New Mexico watershed watch. J. Environ. Educ. 2003, 35, 27-32. [CrossRef]

23. Meichtry, Y.; Smith, J. The impact of a place-based professional development program on teachers' confidence, attitudes and classroom practices. J. Environ. Educ. 2007, 38, 15-32. [CrossRef]

24. Bodzin, A.M. Integrating instructional technologies in a local watershed investigation with urban elementary learners. J. Environ. Educ. 2008, 39, 47-58. [CrossRef]

25. Bossley, J.P.; Smiley, P.C., Jr. Short-term disturbance effects of outdoor education stream classes on aquatic macroinvertebrates. J. Environ. Prot. 2017, 8, 1333-1353. [CrossRef]

26. Bossley, J.P.; Smiley, P.C., Jr. Effects of outdoor education stream classes on substrate movement and macroinvertebrate colonization. J. Freshw. Ecol. 2017, 32, 727-740. [CrossRef]

27. Bossley, J.P. Environmental Impact from Outdoor/Environmental Education Programs: Effects of Frequent Stream Classes on Aquatic Macroinvertebrates. Ph.D. Thesis, Ohio State University, Columbus, $\mathrm{OH}$, USA, 2016.

28. Stream Stats. Available online: https://streamstats.usgs.gov/ss / (accessed on 28 July 2017).

29. L-THIA GLWMS. Available online: http:/ / lthia.agriculture.purdue.edu (accessed on 28 July 2017). 
30. Clifford, H.F. Effects of periodically disturbing a small area of substratum in a brown-water stream of Alberta, Canada. Freshw. Invertebr. Biol. 1982, 1, 39-47. [CrossRef]

31. Doeg, T.J.; Lake, P.S.; Marchant, R. Colonization of experimentally disturbed patches by stream macroinvertebrates in the Acheron River, Victoria. Aust. J. Ecol. 1989, 14, 207-220. [CrossRef]

32. Brooks, S.S.; Boulton, A.J. Recolonization dynamics of benthic macroinvertebrates after artificial and natural disturbances in an Australian temporary stream. Aust. J. Mar. Freshw. Res. 1991, 42, 295-308. [CrossRef]

33. Matthaei, C.D.; Uehlinger, U.; Meyer, E.I.; Frutiger, A. Recolonization by benthic invertebrates after experimental disturbance in a Swiss prealpine river. Freshw. Biol. 1996, 35, 233-248. [CrossRef]

34. Falk, J.H. Estimating experimenter-induced bias in field studies: A cautionary tale. Oikos 1974, 25, 374-378. [CrossRef]

35. Magurran, A.E. Measuring Biological Diversity; Blackwell Publishing: Malden, MA, USA, 2004.

36. Smith, B.; Wilson, J.B. A consumer's guide to evenness indices. Oikos 1996, 76, 70-82. [CrossRef]

37. Voshell, J.R., Jr. A Guide to Common Freshwater Invertebrates of North America; McDonald and Woodward: Blacksburg, VA, USA, 2002.

38. Merritt, R.W.; Cummins, K.W.; Berg, M.B. An Introduction to the Aquatic Insects of North America, 4th ed.; Kendall Hunt Publishing Company: Dubuque, IA, USA, 2008.

39. McCune, B.; Mefford, M.J. PC-ORD Version 6.17. Multivariate Analysis of Ecological Data; MjM Software: Gleneden Beach, OR, USA, 2011.

40. Smiley, P.C., Jr.; Dibble, E.D. Implications of a hierarchical relationship among channel form, instream habitat and stream communities for restoration of channelized streams. Hydrobiologia 2005, 548, 279-292. [CrossRef]

41. Zuur, A.F.; Ieno, A.N.; Smith, G.M. Analysing Ecological Data; Springer: New York, NY, USA, 2007.

42. Fujiki, S.; Aoyagi, R.; Tanaka, A.; Imai, N.; Kusma, A.D.; Kurniawan, Y.; Lee, Y.F.; Sugau, J.B.; Pereira, J.T.; Samejima, H.; et al. Large-scale mapping of tree-community composition as a surrogate of forest degradation in Bornean tropical rain forests. Land 2016, 5, 45. [CrossRef]

43. Bates, D.; Maechler, M.; Bolker, B.; Walker, S. Fitting linear mixed-effects models using lme4. J. Stat. Softw. 2015, 67, 1-48. [CrossRef]

44. Downes, B.J.; Baramuta, L.A.; Fairweather, P.G.; Faith, D.P.; Keough, M.J.; Lake, P.S.; Mapstone, B.D.; Quinn, G.P. Monitoring Ecological Impacts. Concepts and Practice in Flowing Waters; Cambridge University Press: Cambridge, UK, 2002.

45. Fox, J.; Weisberg, S. An R Companion to Applied Regression; Sage Publishing: Thousand Oaks, CA, USA, 2011.

46. $\mathrm{R}$ Core Team. $R$ (Version 3.3.3): A Language and Environment for Statistical Computing; R Foundation for Statistical Computing: Vienna, Austria, 2017.

47. Lenth, R.V. Least-squares means: The R package lsmeans. J. Stat. Softw. 2016, 69, 1-33. [CrossRef]

48. Clarke, K.R. Non-parametric multivariate analyses of changes in community structure. Aust. J. Ecol. 1993, 18, 117-143. [CrossRef]

49. Lepori, F.; Hjerdt, N. Disturbance and aquatic biodiversity: Reconciling contrasting views. Bioscience 2006, 56, 809-818. [CrossRef]

50. Williams, D.D.; Hynes, H.B.N. The occurrence of benthos deep in the substratum of stream. Freshw. Biol. 1974, 4, 233-256. [CrossRef]

51. Angradi, T.; Hood, R.; Tarter, D. Vertical, longitudinal and temporal variation in the macrobenthos of an Appalachian headwater stream system. Am. Midl. Nat. 2001, 146, 223-242. [CrossRef]

52. Xu, M.; Wang, Z.; Pan, B.; Zhao, N. Distribution and species composition of macroinvertebrates in the hyporheic zone of bed sediment. Int. J. Sediment Res. 2012, 27, 129-140. [CrossRef]

53. Mugnai, R.; Messana, G.; Di Lorenzo, T. The hyporheic zone and its functions: Revision and research status in Neotropical regions. Braz. J. Biol. 2015, 75, 524-534. [CrossRef] [PubMed]

54. Stewart, K.W.; Stark, B.P. Nymphs of North American Stonefly Genera (Plecoptera), 2nd ed.; University of North Texas: Denton, TX, USA, 2002.

(C) 2018 by the authors. Licensee MDPI, Basel, Switzerland. This article is an open access article distributed under the terms and conditions of the Creative Commons Attribution (CC BY) license (http:/ / creativecommons.org/licenses/by/4.0/). 